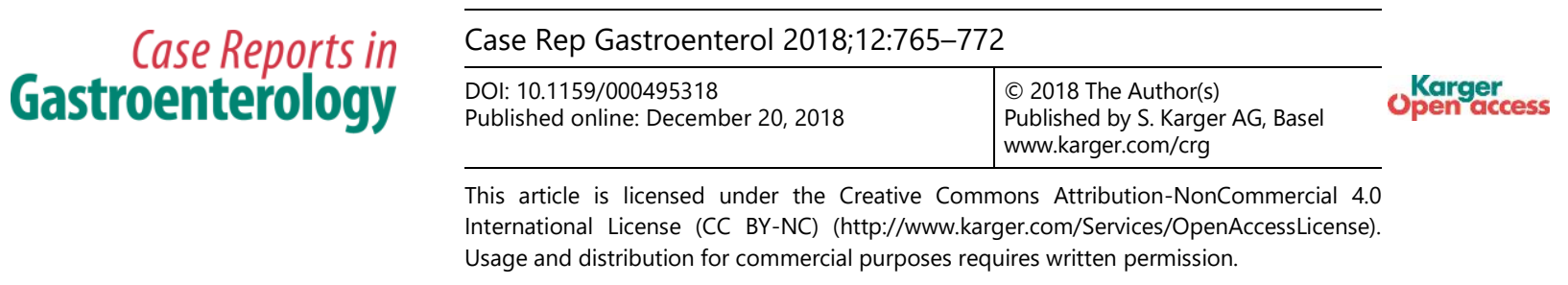

\title{
Pulse Granulomas in Interval Appendectomy Specimens: Histochemical Identification of Cellulose Matter
}

\author{
Shinichi Ban ${ }^{a} \quad$ Akiko Fujii $^{a} \quad$ Toshiro Takimoto $^{a}$ b Kenta Kikuchi $^{c}$ \\ Woodea Kang $^{d}$ Yukiko Namiki ${ }^{a}$ Junichi Koyatsu ${ }^{a}$ Yoshihiko Ueda ${ }^{a}$ \\ aDepartment of Pathology, Dokkyo Medical University Saitama Medical Center, \\ Koshigaya, Japan; ${ }^{b}$ Department of Pathology, Kasukabe Medical Center, Kasukabe, Japan; \\ 'Department of Pediatric Surgery, Dokkyo Medical University Saitama Medical Center, \\ Koshigaya, Japan; dDepartment of Surgery, Kasukabe Medical Center, Kasukabe, Japan
}

\section{Keywords}

Pulse granuloma · Appendix · Appendicitis · Interval appendectomy · Cellulose

\begin{abstract}
Pulse granuloma is a rare pathologic condition considered to be a benign inflammatory reaction to foreign materials originated from ingested legume matter. As for pulse granulomas of the gastrointestinal tract, association with diverticular diseases is relatively common, but only a few pulse granuloma cases associated with appendicitis have been reported. This report presents histopathologic findings of pulse granuloma lesions observed in two appendectomy cases, with some histochemical examinations of cellulose matter which is reportedly a major component to provoke pulse granuloma reaction. Our patients in both cases were girls in their teens, and they underwent interval appendectomy for acute appendicitis. Both appendectomy specimens revealed ruptured walls with inflammatory granulation tissue with marked foreign body reaction including characteristic collections of ring-like, curled ribbon-like, and/or lobulated nephrosclerosis-like hyaline structures and various foreign bodies, in which microorganisms or amyloid deposition were not identified. The presence of cellulose matter was suggested by Sirius red stain, the IKI (iodine potassium iodide) $-\mathrm{H}_{2} \mathrm{SO}_{4}$ method, and birefringence
\end{abstract}




\section{Case Reports in Gastroenterology}

Case Rep Gastroenterol 2018;12:765-772

\begin{tabular}{l|l}
\hline DOI: 10.1159/000495318 & $\odot 2018$ The Author(s). Published by S. Karger AG, Basel \\
\hline
\end{tabular} www.karger.com/crg

Ban et al.: Pulse Granuloma in Interval Appendectomy

by polarized light. Appendectomy materials due to acute appendicitis would include pulse granuloma reaction provoked by ingested materials with cellulose. Pathologists should be familiar with the concept and histopathologic features of pulse granulomas to avoid misinterpreting them as vascular lesions and/or amyloid deposition, or any infectious organisms.

(C) 2018 The Author(s)

Published by S. Karger AG, Basel

\section{Introduction}

Pulse granuloma is a rare pathologic condition, which is reportedly a benign inflammatory reaction to foreign materials originated from ingested legume substances. In addition to well-known oral lesions in edentulous patients or after dental procedures [1,2], pulse granuloma lesions have been reported in the lung [3] and in various other organs and tissues which include the gastrointestinal tract, gallbladder, fallopian tube, skin, and mesenteric lymph nodes [4-8].

As for pulse granuloma lesions observed in the gastrointestinal tract, association with diverticular diseases is relatively common [4, 9]. However, only a few cases of pulse granuloma associated with appendicitis have been described up to today $[4,10,11]$. Herein, we report two additional cases of pulse granuloma lesions localized in the appendices, for which interval appendectomy (IA) were performed with a clinical diagnosis of acute appendicitis. In addition to describing the detailed histopathologic findings of those cases, we tried to identify cellulose matter, which has been reported to be a major component provoking pulse granuloma reaction $[3,12]$, in the pulse granuloma lesions histochemically.

\section{Case Reports}

Case 1

A girl in her early teens visited the emergency department of a community hospital complaining of abdominal pain on the weekend. The next week, she was admitted to the hospital with a diagnosis of acute appendicitis (WBC 14,150/ $\mu \mathrm{L}$, CRP $6.03 \mathrm{mg} / \mathrm{dL}$ ). She was treated conservatively with fasting, transfusion, and antibiotic medication for 3 days and was discharged with the disappearance of the abdominal signs but a persistent elevation of her WBC count $(11,440 / \mu \mathrm{L}$, CRP $0.01 \mathrm{mg} / \mathrm{dL})$. After additional antibiotic medication, her WBC count returned to the reference value $(5,000 / \mu \mathrm{L})$, and she underwent laparoscopic IA at the surgery department of the hospital on day 82 after her emergency department visit. Her postoperative course was uneventful.

\section{Case 2}

A girl in her mid-teens complaining of subumbilical and lower right abdominal pain which had persisted for a week was diagnosed as acute appendicitis with perityphlic abscess formation (WBC 17,900/ $\mathrm{LL}$, CRP $13.9 \mathrm{mg} / \mathrm{dL}$ ) at a community hospital and was transferred to the pediatric surgery department of a university hospital expecting IA. She was treated with antibiotic medication in the hospitals for a week and discharged with alleviated abdominal signs (WBC 7,100/ $\mu \mathrm{L}$ and CRP $0.61 \mathrm{mg} / \mathrm{dL}$ ). She underwent laparoscopic IA at the pediatric surgery department on day 92 after the onset of the abdominal pain. Her postoperative course was uneventful. 


\section{Case Reports in Gastroenterology}

\begin{tabular}{l|l}
\hline Case Rep Gastroenterol 2018;12:765-772 \\
\hline DOI: 10.1159/000495318 & $\begin{array}{l}\text { @ 2018 The Author(s). Published by S. Karger AG, Basel } \\
\text { www.karger.com/crg }\end{array}$ \\
\hline
\end{tabular}

Ban et al.: Pulse Granuloma in Interval Appendectomy

Materials and Methods

The appendectomy specimens of the two cases were cut in round slices and/or longitudinally, and almost every part of the specimens was submitted to the usual histologic examination. In addition to HE preparation, the representative sections were stained by PAS, Grocott methenamine silver, Elastica van Gieson, and Congo red. The same sections were also analyzed to see whether they included cellulose matter by Sirius red stain [13], the IKI (iodine potassium iodide) $-\mathrm{H}_{2} \mathrm{SO}_{4}$ method [14], and observation with polarized light for birefringence. By the IKI- $\mathrm{H}_{2} \mathrm{SO}_{4}$ method, in which the deparaffinized histologic sections were immersed in IKI solution for $15 \mathrm{~min}$ followed by dropping of $65 \% \mathrm{H}_{2} \mathrm{SO}_{4}$, cellulose matter in the sections would change their color to blue.

\section{Pathologic Findings}

Both appendectomy materials showed ruptures and perforations of the wall. In Case 1, the inflammatory granulation tissue formed around the fibrously obliterative appendix was mostly composed of "pulse granuloma" lesions (Fig. 1a, b) whereas in Case 2, the "pulse granuloma" lesions were focally observed in the suppurative inflammatory granulation tissue forming a perforated turbid mass (Fig. 1c, d).

The "pulse granuloma" lesions were composed of inflammatory granulation tissue characterized by collections of ring-like, curled ribbon-like, and/or lobulated nephrosclerosis-like hyaline structures with the infiltration of chronic inflammatory cells, macrophages, and many foreign-body-type multinucleated giant cells, but without epithelioid cell granuloma formation (Fig. 2a, b). Various foreign materials were observed including: (1) cork-like or cell sheet-like structures surrounded by multinucleated giant cells, suggestive of vegetable matter (Fig. 2c), (2) basophilic globular or rod-like bodies engulfed by multinucleated giant cells (Fig. 2d), and (3) yellowish-brown small fragments (Fig. 2e).

Hyaline structures and foreign materials were variously reactive for PAS and PAS with diastase digestion. Basophilic globular or rod-like bodies, cork-like or cell sheet-like structures, and some hyaline ring-like structures were stained by Sirius red (Fig. 3a, b), and partly birefringent by polarized light (Fig. 3c). Hyaline structures and some foreign materials changed their color to blue by the IKI- $\mathrm{H}_{2} \mathrm{SO}_{4}$ method (Fig. 3d). Yellowish-brown small fragments were negative for Berlin blue, although multinucleated giant cells contained stainable iron. Elastic fibers suggestive of vascular structures were not revealed in hyaline structures by Elastica van Gieson stain, and no amyloid deposition was identified with Congo red. Microorganisms such as fungi were not revealed with PAS and Grocott methenamine silver.

\section{Discussion}

The present appendectomy specimens had characteristic inflammatory granulation tissue showing peculiar ring-like, curled ribbon-like, and/or lobulated nephrosclerosis-like hyaline structures with foreign-body reaction. They were somewhat reminiscent of hyalinized vasculature with/without amyloid deposition, but no lamellar elastic fibers suggestive of vascular structures nor amyloid deposition were identified by Elastica van Gieson and Congo red stains, respectively. Besides, PAS and Grocott methenamine silver stains did not reveal microorganisms such as fungi. Excluding those, the peculiar hyaline structures were consistent with lesions referred to as "pulse granuloma," which has been well-known as oral lesions in edentulous patients or after dental procedures $[1,2]$. 


\section{Case Reports in Gastroenterology}

Case Rep Gastroenterol 2018;12:765-772

DOI: $10.1159 / 000495318$

(c) 2018 The Author(s). Published by S. Karger AG, Basel

www.karger.com/crg

Ban et al.: Pulse Granuloma in Interval Appendectomy

Previous histologic and ultrastructural observations and studies using animal models have revealed that pulse granuloma lesions, including oral and extraoral lesions, are an inflammatory reaction to foreign materials originated from ingested legume matter $[1,3,4,10$, $12]$, especially to a cellulose component within them $[3,12]$. Also, in the present cases, corklike or cell sheet-like figures suggestive of vegetable matter origin were identified with foreign body reaction. Those figures and other foreign materials showing basophilic globular or rodlike figures were positive for Sirius red and birefringent by polarized light. Sirius red stain is one of the staining methods for amyloid, but it can reportedly identify cellulose components in various forms in tissue sections [13]. Besides, cellulose is the most plausible birefringent material of higher plant origin. In addition, the hyalinized components turned blue with the classical IKI- $\mathrm{H}_{2} \mathrm{SO}_{4}$ method, which is a sensitive histochemical method to identify cellulose [14]. Thus, foreign materials causing "pulse granuloma" reaction in the present cases could include cellulose matter. However, the positive finding sites were not always identical by every method to detect cellulose components, probably suggesting a variability of their degradative and/or degenerative phases losing their original characteristics. Very recently, the presence of cellulose in oral pulse granuloma lesions has additionally been confirmed by staining with a biotinylated carbohydrate-binding module of exoglucanases which specifically bind cellulose [15].

Although the pulse granuloma reaction is generally considered to be a rare event, in addition to oral lesions, it has been reported in the lung [3] and in various other organs and tissues including the gastrointestinal tract, gallbladder, fallopian tube, skin, mesocolonic lymph node and fat, and prostate [4-8]. In any of the cases, vegetable matter needs to be introduced into the tissues for the pulse granuloma reactions. Pulmonary lesions are believed to be caused by aspiration [3], and gastrointestinal tract lesions would require wall injury and/or rupture. Lesions of other organs are due to fistula formation between the gastrointestinal tract [6-8]. One very rare prostate case was attributed to the needle biopsy which displaced the vegetable matter transrectally to the prostate [7].

Considering the causative agents, the gastrointestinal tract seems to be a susceptible site for pulse granuloma lesions. However, it is not easy to determine the real incidence of pulse granuloma in the gastrointestinal tract because not all lesions with pulse granulomas can be histopathologically examined. A recent study reported an incidence rate of $9 \%$ in a retrospective review of gastrointestinal specimens resected for ulcerative and/or perforated lesions [9], which suggests that pulse granulomas would not be so rare and would be overlooked in routine pathologic examinations. Regarding that point, the most notable lesion seems to be diverticular disease, which has reportedly been the most frequent associated prior disease in pulse granuloma case series $[4,9]$.

On the other hand, only a few pulse granuloma cases associated with appendicitis have been reported $[4,10,11]$, in which wall injuries such as ulceration [10] and rupture [4] would be required as well for the establishment of the lesion. The present cases also revealed the rupture of the appendiceal wall. Of note, in the present cases, both patients underwent IA. Considering that foreign body and/or granulomatous reactions are frequently observed in IA specimens [16, 17], it is plausible that pulse granulomas could be involved in some IA specimens due to ruptured and/or abscess-forming acute appendicitis. It may be necessary to reevaluate those materials.

Evaluating a relatively large number of pulse granuloma lesions of the gastrointestinal tract, Nowacki at al. [4] described two types of pulse granuloma lesions including "hyaline predominant" and "cellular predominant," suggesting the former being relatively earlier and the latter relatively older chronologically. The present two cases were also different in 


\section{Case Reports in Gastroenterology}

\begin{tabular}{l|l}
\hline Case Rep Gastroenterol 2018;12:765-772 \\
\hline DOI: 10.1159/000495318 & $\begin{array}{l}\text { ( ) 2018 The Author(s). Published by S. Karger AG, Basel } \\
\text { www.karger.com/crg }\end{array}$ \\
\hline
\end{tabular}

Ban et al.: Pulse Granuloma in Interval Appendectomy

histologic figures, one being entirely "hyaline predominant," and the other focally showing hyaline structures in suppurative inflammatory granulation tissue, probably corresponding to the classification by Nowacki et al. [4], respectively. However, the duration from the onset to the appendectomy was not so different between the two cases. Therefore, those differences in histologic figures might not be entirely attributable to the chronologic factor, but could be influenced by, for example, the quality and/or quantity of the causative materials, concomitant irritative factors, responsiveness to the antibiotic therapy, and so forth.

By reporting the preset cases, we would like to stress that appendectomy specimens due to acute appendicitis could include pulse granuloma reaction provoked by ingested materials with cellulose. Pathologists should be familiar with the concept and histopathologic features of pulse granulomas to avoid misinterpreting them as vascular lesions and/or amyloid deposition, or any infectious organisms.

\section{Statement of Ethics}

The authors have no ethical conflicts to disclose.

\section{Disclosure Statement}

The authors have no conflicts of interest to disclose.

\section{References}

1 Harrison JD, Martin IC. Oral vegetable granuloma: ultrastructural and histological study. J Oral Pathol. 1986 Jul;15(6):322-6.

2 Talacko AA, Radden BG. Oral pulse granuloma: clinical and histopathological features. A review of 62 cases. Int J Oral Maxillofac Surg. 1988 Dec;17(6):343-6.

3 Knoblich R. Pulmonary granulomatosis caused by vegetable particles. So-called lentil pulse pneumonia. Am Rev Respir Dis. 1969 Mar;99(3):380-9.

4 Nowacki NB, Arnold MA, Frankel WL, Harzman A, Limketkai BN, Yearsley MM, et al. Gastrointestinal tractderived pulse granulomata: clues to an underrecognized pseudotumor. Am J Surg Pathol. 2015 Jan;39(1):8492.

5 Pereira TC, Prichard JW, Khalid M, Medich DS, Silverman JF. Rectal pulse granuloma. Arch Pathol Lab Med. 2001 Jun;125(6):822-3.

6 Rhee DD, Wu ML. Pulse granulomas detected in gallbladder, fallopian tube, and skin. Arch Pathol Lab Med. 2006 Dec;130(12):1839-42.

7 Karamurzin YS, Narula S, Khanifar E, Kim YS, Wu ML. Pulse granulomas in highly unusual sites. Histopathology. 2009 Jan;54(2):268-9.

8 DeRoche TC, Gates GA, Huber AR. Pulse Granulomas of the Gastrointestinal Tract and Gallbladder: Report of Five Cases. Case Rep Pathol. 2017;2017:2497945

9 Gonzalez RS. Incidence of Pulse Granuloma in the Small and Large Intestines. Am J Surg Pathol. 2016 Jan;40(1):137-40.

10 Veress B, Alafuzoff I, Juliusson G. Granulomatous peritonitis and appendicitis of food starch origin. Gut. 1991 Jun;32(6):718-20.

11 Şımşek GG, Buluş H, Güreşç S. Pulse granuloma, unusual localization: appendix. Turk J Gastroenterol. 2012 Aug;23(4):417-8.

12 Talacko AA, Radden BG. The pathogenesis of oral pulse granuloma: an animal model. J Oral Pathol. 1988 Mar;17(3):99-105.

13 Lewin-Smith MR, Kalasinsky VF, Mullick FG. Histochemical identification of microcrystalline cellulose, calcium oxalate, and talc in tissue sections. Arch Pathol Lab Med. 2011 Aug;135(8):963.

14 Jensen WA. Botanical Histochemistry. San Francisco: W.H. Freeman and Co.; 1962. 


\section{Case Reports in Gastroenterology}

\begin{tabular}{l|l}
\hline Case Rep Gastroenterol 2018;12:765-772 \\
\hline DOI: 10.1159/000495318 & $\begin{array}{l}\text { C 2018 The Author(s). Published by S. Karger AG, Basel } \\
\text { www.karger.com/crg }\end{array}$ \\
\hline
\end{tabular}

Ban et al.: Pulse Granuloma in Interval Appendectomy

15 Virkkunen S, Wolff H, Haglund C, Højgaard C, Winther JR, Willemoës M, et al. Positive staining for cellulose in oral pulse granuloma. Oral Surg Oral Med Oral Pathol Oral Radiol. 2017 Apr;123(4):464-7.

16 Guo G, Greenson JK. Histopathology of interval (delayed) appendectomy specimens: strong association with granulomatous and xanthogranulomatous appendicitis. Am J Surg Pathol. 2003 Aug;27(8):1147-51.

17 Otake S, Suzuki N, Takahashi A, Toki F, Nishi A, Yamamoto H, et al. Histological analysis of appendices removed during interval appendectomy after conservative management of pediatric patients with acute appendicitis with an inflammatory mass or abscess. Surg Today. 2014 Aug;44(8):1400-5.
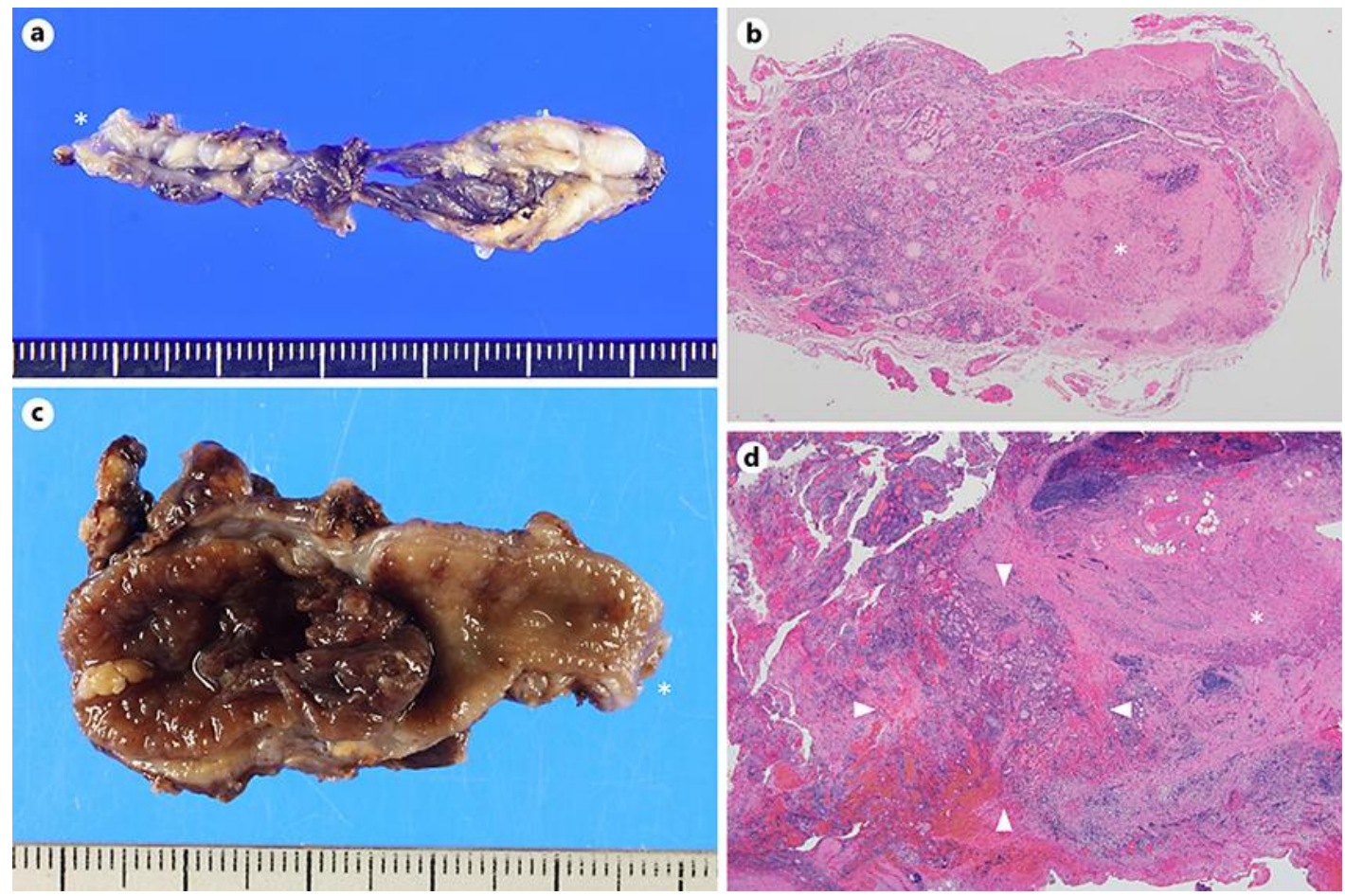

Fig. 1. Appendectomy specimens of Case $1(\mathbf{a}, \mathbf{b})$ and Case 2 (c, d). a Gross appearance after longitudinal incision and formalin fixation measuring $6 \times 1.5 \mathrm{~cm}$, showing atrophy and hemorrhage with focal rupture of the wall. * Resection margin. $\mathbf{b}$ Low-power histologic view of the axial section, showing luminal fibrous obliteration $\left({ }^{*}\right)$ and peri-appendiceal inflammatory granulation tissue formation with fibrino-hemorrhagic exudate, the latter being consistent with "pulse granuloma." Original magnification $\times 40$. c Gross appearance after longitudinal incision and formalin fixation measuring $5 \times 1.5 \times 2.5 \mathrm{~cm}$, showing enlargement of the distal two thirds with luminal dilation, turbid hemorrhagic mass, and perforation. * Resection margin. $\mathbf{d}$ Low-power histologic view of the axial section of the perforated turbid mass showing hemorrhagic inflammatory granulation tissue, including the "pulse granuloma" area indicated by arrow heads. * Muscularis propria. Original magnification $\times 20$. 


\section{Case Reports in Gastroenterology}

Case Rep Gastroenterol 2018;12:765-772

DOI: $10.1159 / 000495318$

(c) 2018 The Author(s). Published by S. Karger AG, Basel www.karger.com/crg

Ban et al.: Pulse Granuloma in Interval Appendectomy
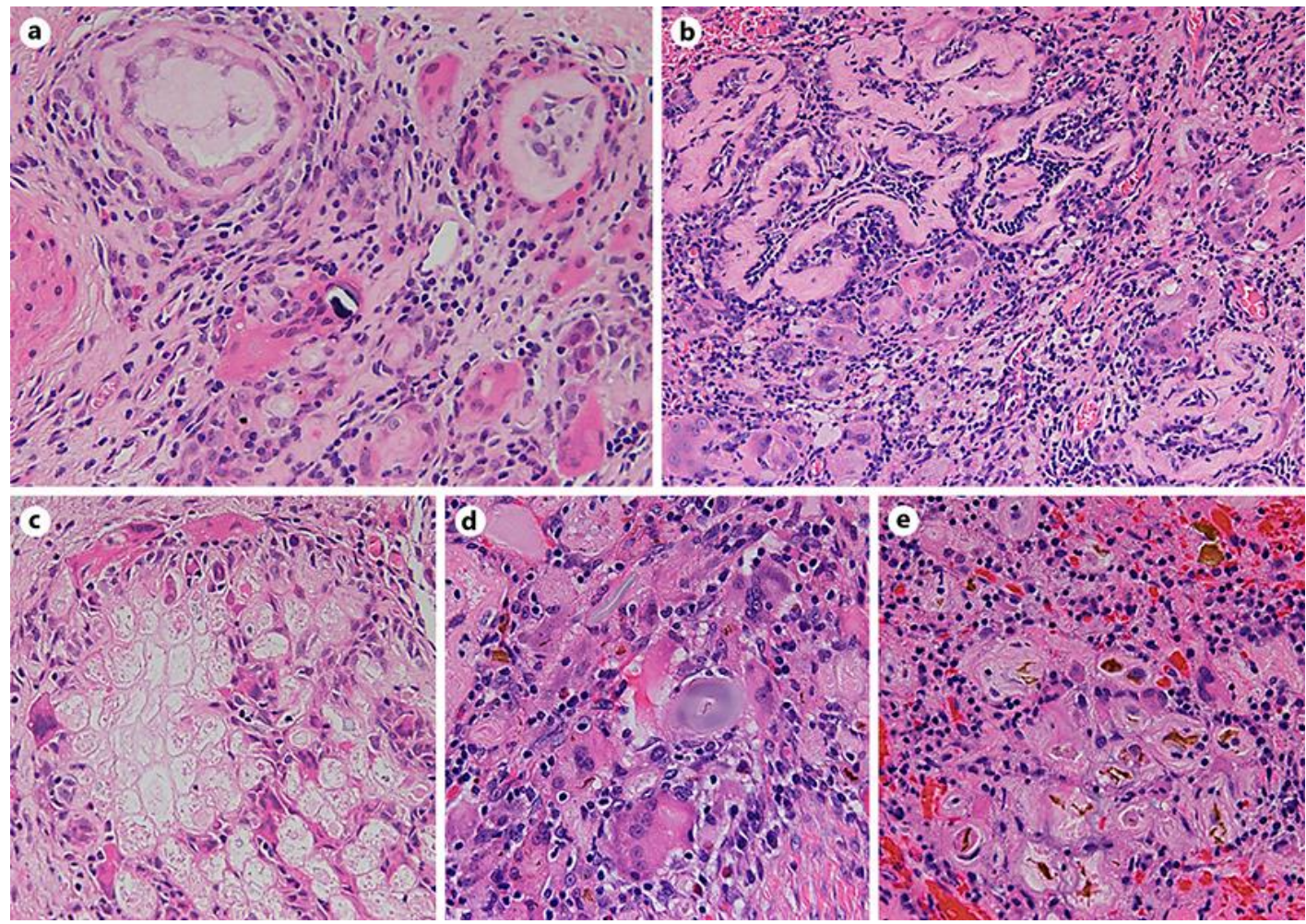

Fig. 2. High-power histologic views of the "pulse granuloma" lesions. a, b Peri-appendiceal inflammatory granulation tissue of Case 1, showing collections of characteristic ring-like, curled ribbon-like, and/or lobulated nephrosclerosis-like hyaline structures, and many foreign-body-type multinucleated giant cells. ce Various foreign materials in the inflammatory granulation tissue, including cork-like structures surround by multinucleated giant cells (c, Case 1), basophilic globular or rod-like bodies engulfed by multinucleated giant cells (d, Case 2), and yellowish-brown small fragments (e, Case 2). a, c-e Original magnification $\times 400$. b Original magnification $\times 200$. 


\begin{tabular}{|c|c|c|}
\hline \multirow{3}{*}{$\begin{array}{r}\text { Case Reports in } \\
\text { Gastroenterology }\end{array}$} & \multirow{2}{*}{\multicolumn{2}{|c|}{ Case Rep Gastroenterol 2018;12:765-772 }} \\
\hline & & \\
\hline & DOI: $10.1159 / 000495318$ & $\begin{array}{l}\text { (c) } 2018 \text { The Author(s). Published by S. Karger AG, Basel } \\
\text { www.karger.com/crg }\end{array}$ \\
\hline
\end{tabular}

Ban et al.: Pulse Granuloma in Interval Appendectomy
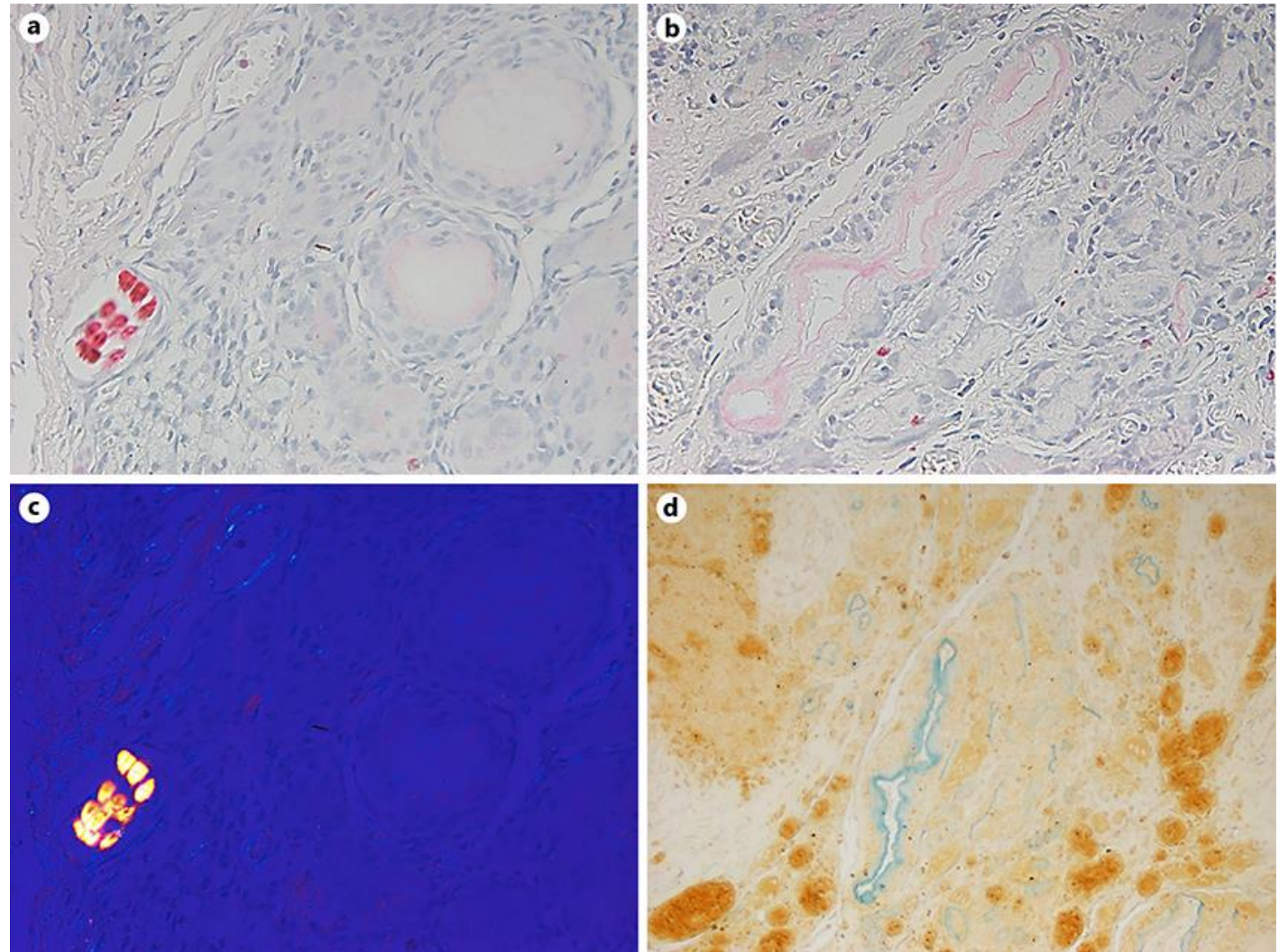

Fig. 3. Results of special stains and birefringence by polarized light. a, b Sirius red staining showing the hyaline ring-like structures lightly stained red (right in a and center in $\mathbf{b}$ ), and the cell sheet-like structure brightly stained red (left in a). c The cell sheet-like structure being birefringent by polarized light (the same structure as the one showing a bright red stain in a). $\mathbf{d}$ The hyaline ring-like structure turned to blue by the IKI- $\mathrm{H}_{2} \mathrm{SO}_{4}$ method (the same structure as the one showing a light red stain in $\mathbf{b}$ ). a-c Original magnification $\times 400$. d Original magnification $\times 200$. 